\title{
Growth-Climate Response of Young Turkey Oak (Quercus cerris L.) Coppice Forest Stands along Longitudinal Gradient in Albania
}

\author{
Merita Stafasani ${ }^{1 凶}$, Elvin Toromani ${ }^{1}$
}

\author{
${ }^{1}$ Agricultural University of Tirana, Faculty of Forestry Sciences, Koder Kamez, AL-1029 Tirana, Albania \\ $\triangle$ Corresponding author: e-mail: meritastafasani@yahoo.com
}

Citation:

STAFASANI M, TOROMANI E 2015 Growth-Climate Response of Young Turkey Oak (Quercus cerris L.) Coppice Forest Stands along Longitudinal Gradient in Albania. South-east Eur for 6 (1): 25-38. DOI: http://dx.doi.org/10.15177/seefor.15-05

\begin{abstract}
Background and Purpose: Turkey oak (Quercus cerris L.) is the most widespread species in Albania and less investigated from dendroclimatological point of view. Previous studies have reported that $Q$. cerris is sensitive to the environment when growing at different latitudes and ecological conditions. Based on this fact we have explored the response of different $Q$. cerris populations located along the longitudinal gradient.

Materials and Methods: The stem discs were sampled from six sites (Kukes, Diber, Rreshen, Ulez, Elbasan, Belsh) along longitudinal gradient ranging from north-east to central Albania. All oak forests stands grow under the influence of specific local Mediterranean climate. Tree-ring widths were measured to the nearest $0.001 \mathrm{~mm}$ using a linear table, LINTAB and the TSAP-Win program. Following the standard dendrochronological procedures residual tree-ring width chronologies were built for each site. Statistical parameters commonly used in dendrochronology were calculated for each site chronology. Relations between the tree-ring chronologies were explored using Hierarchical Factor Classification (HFC) and Principal Component Analysis (PCA), while the radial growth-climate relationship was analyzed through correlation analysis using a 19-month window from April in the year prior to tree-ring formation (year $t-1$ ) until October in the year of growth (year $\mathrm{t}$ ).

Results and Conclusions: The length of the site chronologies ranged from 16 to 36 years, with the Elbasan site chronology being the longest and the Belsh site chronology the shortest one. Trees at lower elevation were younger than trees at higher elevation. Statistical parameters (mean sensitivity (MS) and auto correlation (AC)) of site chronologies were different among them and lower values of AC1 showed a weaker dependence of radial growth from climatic conditions of the previous growing year. Principal component analysis showed that Belsh, Rreshen and Elbasan site chronologies were clustered in the first principal component accounted $36.6 \%$ of the total variance. The HFC indicated grouping of the site chronologies in two clusters, where Belsh, Rreshen and Elbasan site chronologies were grouped in the first cluster while Kukes, Diber and Ulez in the second one, confirming the results previously provided from
\end{abstract}


PCA. The dendroclimatological analyses showed that the positive moisture balance in current April and previous September was the dominant climatic factor favoring the radial growth of $Q$. cerris in Albania.

Keywords: dendroclimatology, principal component analysis, hierarchical cluster analysis, correlation analysis

\section{INTRODUCTION}

The genus Quercus is one of the most important clades of woody angiosperms in the Central and Western Europe, in terms of species diversity, ecological dominance, and economic value [1]. Turkey oak as one of the species of this genus is grown in England, France, Italy, Balkan Peninsula, as well as in Albania. The genus Quercus in Albania is mainly represented by Turkey oak (Quercus cerris L.), Italian oak (Quercus frainetto Ten.), Pedunculate oak (Quercus robur L.) and Sessile oak (Quercus petraea Liebl.). Q. cerris is the most widespread species in Albania, covering 132910 ha (30.8\% of overall forest area) with a standing volume of 2.5 million $\mathrm{m}^{3}$, dominated by young forest stands ranging from the age of 10 to 20 years [2]. Oak forests in Albania are managed in two ways: coppice and high forests. However, there are some forests under mixed management. In general, about $74 \%$ of oak forests are coppice and $26 \%$ are high forests. Because they are managed as coppice, oak forests are often clear cut and managed with short rotation. This is the reason why they are so young.

Among the deciduous oaks, Turkey oak is less investigated from a dendrochronological point of view. In Albania, there are several studies related to this species focusing on silvicultural aspects [3], but there are no chronologies available, nor any study about radial growth and its response to climate.

The natural stands of this species in Albania grow under the Mediterranean climate conditions, characterized by dry and hot summers and wet and cold winters, both periods unfavorable for growth [4-6]. Oak forests in low altitude sites face a lack of moisture during summer and the water shortage during these months of the growing season reduces the radial growth.
Tree ring analysis is considered as a powerful tool for the identification of the most important relations between the tree radial growth and the climate [7-9]. In dendrochronological studies the inter-annual response of radial growth to local climate variations is evaluated through the study of the relation between the total tree-ring width and the climate data [10]. Tree-ring responses of Turkey oak to climate fluctuations have been widely studied in Italy [11, 12], Serbia [13], Slovakia [14], etc.

Previous studies have also reported that Turkey oak is sensitive to local climatic conditions and to those sites located at different altitudes [15]. This characteristic initiated the idea to investigate the response of the radial growth of young $Q$. cerris populations located along the longitudinal gradient to different local climate conditions. Because all Turkey oak forest stands are conventionally managed as coppice in the climate-growth analysis, we were constrained in selection of such young oak stands.

Therefore the objectives of this study were: i) to develop first $Q$. cerris chronologies for different sites, ii) to study the radial growthclimate relationship along the longitudinal gradient and iii) to study the response of the radial growth of $Q$. cerris to local and regional climate.

\section{MATERIALS AND METHODS}

\section{Research Locations}

The study was carried out in six sites along longitudinal gradient (Figure 1). In the northeast part our sampling sites were Kukes (KUK) and Diber (DIB), in the northern central part of Albania we chose Ulza (UL) and Rreshen (RESH), while from southern-central Albania we took samples from Graceni (ELB) and Belsh (BEL). All studied sites represent the natural 


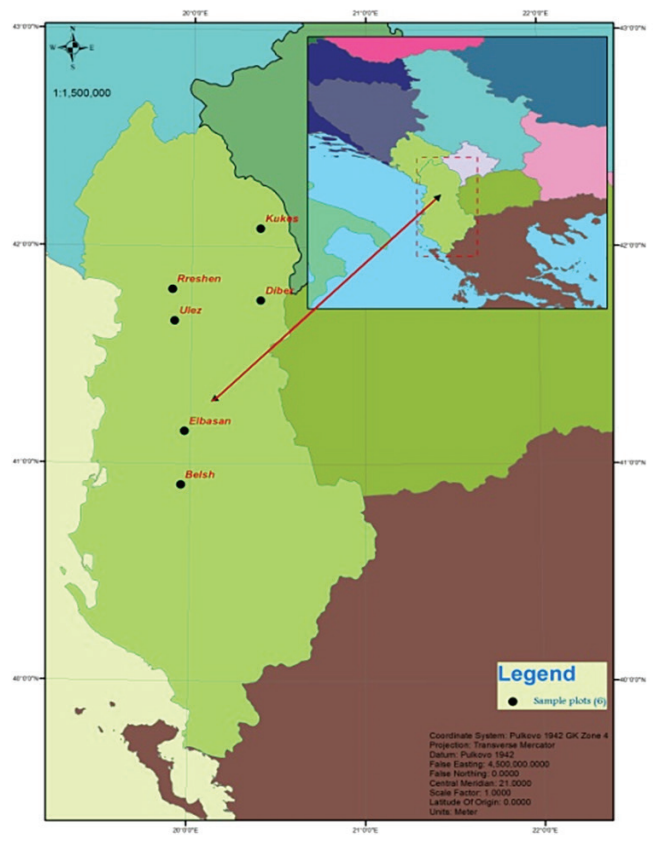

FIGURE 1. The location of sampling sites in the map

habitats of mixed forest stands of Turkish oak (Q. cerris L.) and Macedonian oak (Q. frainetto Ten.) managed intensively as coppice for a long time. The study sites are located in different exposition and in a broad altitudinal range from 240 m until 692 m a.s.I (Table 1). Natural understory vegetation consists of common hornbeam (Carpinus betulus L.), common juniper (Juniperus communis L.), common hawthorn (Crataegus monogyna Jacq.) and herbaceous vegetation. These forest stands are grown on brown soils formed on limestone bedrock. Such soils have medium thickness with a sub-clay structure.

\section{Climate of the Studied Areas}

The KUK site is in a hilly area and it has a Mediterranean climate [16] with harsh winters and abundant rainfall. The mean annual temperature is $11.2^{\circ} \mathrm{C}$, with long-term mean total annual rainfall reaching the value of $850 \mathrm{~mm}$. The coldest month is January $\left(-3^{\circ} \mathrm{C}\right)$, while the warmest month is July $\left(21.9^{\circ} \mathrm{C}\right)$. Precipitation has a non-uniform distribution, with the highest amount of precipitation during winter $(321.7 \mathrm{~mm})$ and the lowest amount during summer (100 $\mathrm{mm}$ ) (Figure 2).

The DIB site is also in a hilly area and it has a Mediterranean climate [16] with a mean annual temperature of $8.2^{\circ} \mathrm{C}$. The coldest month in this site is January $\left(-2.4^{\circ} \mathrm{C}\right)$ and the warmest is August $\left(19^{\circ} \mathrm{C}\right)$. The amount of precipitation is $990 \mathrm{~mm}$ per year on average. The majority of precipitation falls in winter $(366.9 \mathrm{~mm})$ where January is the wettest month $(175.6 \mathrm{~mm})$, whereas the driest month is July $(49.2 \mathrm{~mm})$. For both sites snow is a common phenomenon during the winter period.

The RRESH and UL Turkey oak natural stands are growing under the influence of the northern central hilly area with a Mediterranean climate. The long-term mean annual temperature in both sites is $13.5^{\circ} \mathrm{C}$. The lowest recorded

TABLE 1. Characteristics (mean \pm standard deviation) of the sampled trees and altitude of the studied sites

\begin{tabular}{lcccc}
\hline \multicolumn{1}{c}{ Site } & $\begin{array}{c}\text { Altitude } \\
(\mathrm{m} \text { a.s.I. })\end{array}$ & $\begin{array}{c}\text { DBH } \\
(\mathrm{cm})\end{array}$ & $\begin{array}{c}\text { H } \\
(\mathrm{m})\end{array}$ & $\begin{array}{c}\text { Age } \\
\text { (years) }\end{array}$ \\
\hline Kukes (KUK) & 365 & $6.9 \pm 4.5$ & $6.0 \pm 2.2$ & $28.0 \pm 7.0$ \\
Diber (DIB) & 616 & $10.7 \pm 8.2$ & $7.0 \pm 2.5$ & $22.0 \pm 5.0$ \\
Rreshen (RRESH) & 240 & $7.0 \pm 4.1$ & $4.5 \pm 1.7$ & $18.0 \pm 6.0$ \\
Ulez (UL) & 241 & $6.9 \pm 2.9$ & $7.0 \pm 2.5$ & $21.0 \pm 6.0$ \\
Elbasan (ELB) & 692 & $20.7 \pm 12.9$ & $15.5 \pm 3.1$ & $36.0 \pm 7.0$ \\
Belsh (BEL) & 136 & $9.4 \pm 5.9$ & $7.4 \pm 3.5$ & $16.0 \pm 1.0$ \\
\hline
\end{tabular}

$\mathrm{DBH}$ - diameter at breast height; $\mathrm{H}$ - tree height 

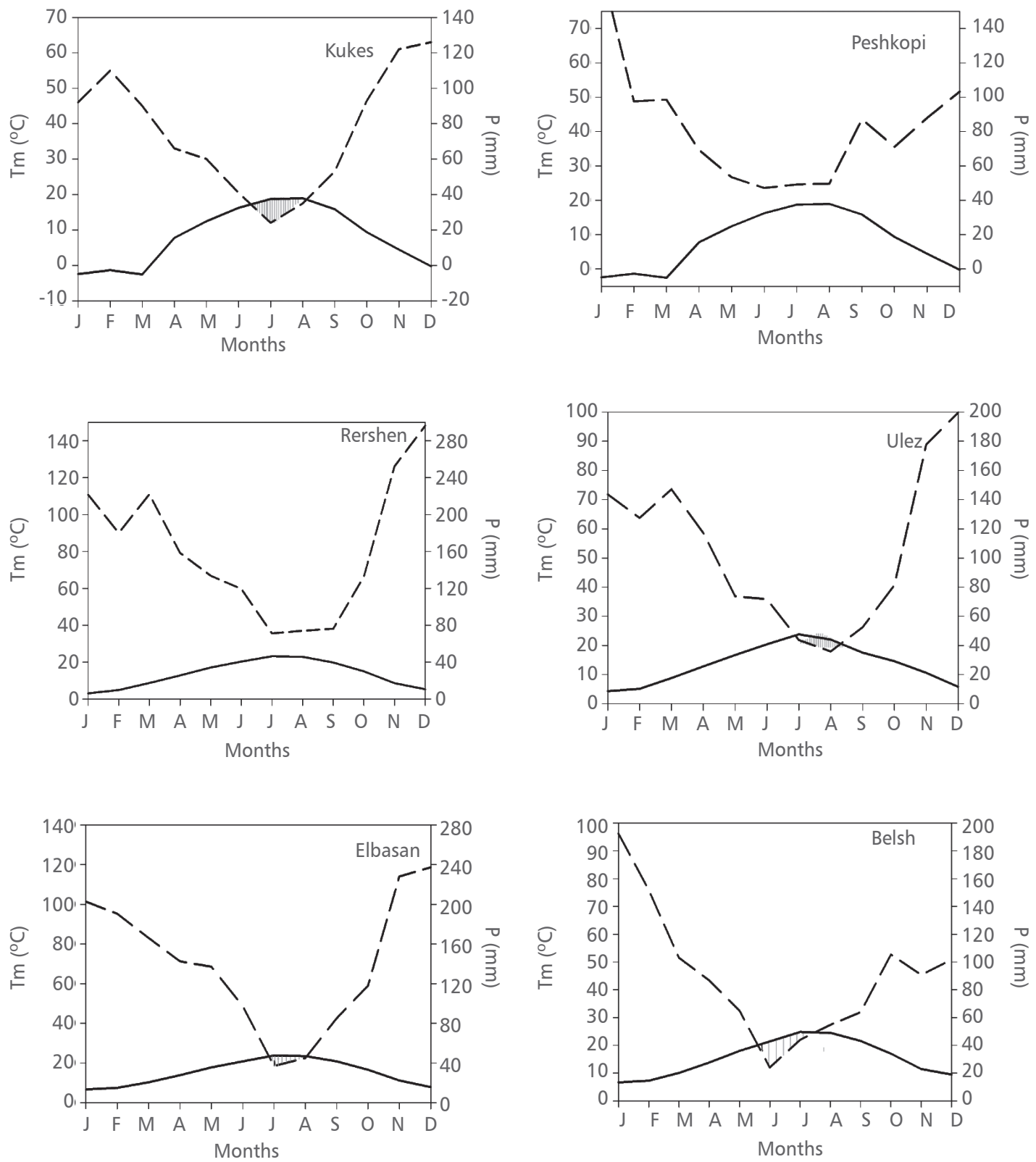

FIGURE 2. Climate diagrams of the studied sites along longitudinal gradient. Dashed lines indicate monthly total precipitation and solid lines mean monthly temperatures.

temperature for RRESH and UL sites is $3.1^{\circ} \mathrm{C}$ and $4.3^{\circ} \mathrm{C}$ in January respectively, while the warmest month is July $\left(23.2^{\circ} \mathrm{C}\right.$ and $23.8^{\circ} \mathrm{C}$ respectively). The long-term mean annual sum of precipitation is $1937 \mathrm{~mm}$ for RRESH and $1271 \mathrm{~mm}$ for UL site.
The wettest month for both sites is December (296.2 mm (RRESH) and $199.7 \mathrm{~mm}$ (UL)), while July $(71.1 \mathrm{~mm})$ and August $(35.8 \mathrm{~mm})$ are the driest months for RRESH and UL. The snow is a temporal phenomenon in both sites during 
winter, affecting the moisture soil balance, especially in the start of the cambial activity of Turkey oak species.

The ELB and BEL sites have a southern central Mediterranean climate. The mean annual temperature is $12.2^{\circ} \mathrm{C}$ and $15.5^{\circ} \mathrm{C}$ for ELB and BEL respectively. The minimum temperature for ELB is $5.2^{\circ} \mathrm{C}$ (January) and the maximum $21.7^{\circ} \mathrm{C}$ (August), while for BEL the lowest temperatures is $6.7^{\circ} \mathrm{C}$ (January) and the highest $\left(24.8^{\circ} \mathrm{C}\right)$ was recorded in July. The total amount of precipitation is $1271.2 \mathrm{~mm}$ (ELB) and $1745 \mathrm{~mm}$ (BEL) per year. The highest amount of precipitation in both sites falls during winter and spring, with November, December, January and February being the wettest months and summer months being the driest. Summer months are drier in BEL site where the longterm monthly sum precipitation recorded was $122.6 \mathrm{~mm}$, whereas in ELB site the amount of summer precipitation was $216.7 \mathrm{~mm}$ on average. The driest months are July and August for ELB and June and July for BEL site. Snow is common for ELB site, lasting on average 17 days and usually falling in January or February, but is not a common phenomenon for BEL site.

\section{Tree Sampling}

Dominant healthy trees with no damage were selected for sampling at all study sites. The core sampling at first five sites was carried out during the period from October to November 2012, while the samples from Belshi area were taken in February 2014. From 8 to 18 sample trees were cut at each site. Three stem discs from the bole, middle and top of the stem were taken from each tree. The stem discs were air dried and sanded until the tree-ring patterns were perfectly visible. Tree-ring width (TRW) was measured to the nearest $0.001 \mathrm{~mm}$ using a linear table, LINTAB (Frank Rinn S.A, Heidelberg, Germany) and the TSAP-Win program. For each sampled tree, height $(\mathrm{H})$ was measured with Vertex, while diameter at breast height (DBH) with caliper.

TRW series were cross-dated and checked visually and statistically using PAST- $4^{\mathrm{TM}}$ software (www.sciem.com). Firstly, visual on-screen comparison was done after TRW measuring and then statistical cross- dating was conducted by calculating statistical parameters, such as the t-value according to Baillie and Pilcher $\left(t_{B P}\right)$ [17] and Gleichlaufigkeit coefficient (GLK\%) [18]. Additional quality control was applied using the COFECHA program [19].

The cross-dated ring width series were detrended and standardized to remove age-related growth trends [7, 20]. The standardisation was performed with the ARSTAN software [21]. A negative exponential function was fitted to the raw data and then the original values were subtracted from the fitted ones. The residual series were averaged using a bi-weight robust mean function to construct residual chronologies of TRW for each site.

Statistical parameters commonly used in dendrochronology were calculated: 1) mean sensitivity (MS), which is a measure of the relative change in ring widths between successive years, 2 ) the first order autocorrelation (AC1), which reflects the influence of the previous year's growth on current growth with a time lag of one year [7] and 3) expressed population signal (EPS), which quantifies how well a chronology based on a finite number of trees represents the hypothetical perfect or true chronology. The first two parameters indicate the sensitivity of the species growth to environmental factors, while the EPS was used to evaluate the climatic signal of each chronology [22].

Considering the relatively young age of the trees, we used the residual chronology (RES), since the RES contains more high-frequency signals and is better in examining the growthclimate relationship in the study area. In the following analyses the period 1998-2012 which is common to all chronologies has been taken into account. In this common period all studied chronologies reached an EPS higher than the theoretical threshold of 0.85 .

\section{Multidimensional Analysis}

The relations between the tree-ring chronologies were explored using hierarchical factor classification and principal component analysis. The first analysis made a classification of the 
series based on their similarity, while the last one made an ordination of the RW series based on their variance. The Principal Component Analysis (PCA) was run for the ordination $[23,24]$. We applied the Varimax with Kaiser Normalization rotation method and, according to Kaisser-Guttman's rule [25], we decided to take into account only the principal components with eigenvalues larger than 1.

Moreover, for series classification we applied the Hierarchical Factor Classification (HFC) [26]. We performed HFC to classify Turkey oak site chronologies into meaningful groups and subgroups. The HFC clustered the oak radial growth chronologies based on their similarity and variance homogeneity. Thus, one cluster or node is established by merging two or more oak chronologies. The HFC can simultaneously be both a classification and a factor analysis tool and therefore different clusters of grouped chronologies can be distinguished [27, 28]. At each cluster node, the first component represents what the merging groups of chronologies have in common, whereas the second one represents the main differences between the clusters [27]. In the HFC analysis, the fusion level is a measure of the diversity of the groups obtained by cutting the dendrogram at each level.The PCA and HFC analyses were performed using SPSS 17 software (SPSS inc).

\section{Growth - Climate Relationship}

The radial growth-climate relationship was analyzed through correlation analysis. We had access over two sources of climate data - local meteorological information from meteorological stations of Kukesi, Peshkopi, Burreli, Elbasani, Belshi and Shkodra which were used to produce climatic diagrams of the study sites (Figure 2) and a gridded CRU TS 3.1 temperature and precipitation dataset for the 1901-2009 period with a grid resolution of $0.5 \times 0.5^{\circ}$ [29]. The CRU dataset used in this study was extracted from the database using the KNMI Climate Explorer web page (http:// climexp.knmi.nl/). We extracted climate dataset for the region encompassed by the coordinates $40^{\circ} 25^{\prime}-42^{\circ} 25^{\prime} \mathrm{N}$ and $19^{\circ} 25^{\prime}-20^{\circ} 25^{\prime} \mathrm{E}$.
When we compared local climate datasets with the gridded CRU TS 3.1 dataset, it was ascertained that these climate data were not sufficiently reliable, mainly due to the lack of homogenization, missing values and brevity. Therefore, we took these datasets only as a reference, to which the CRU TS 3.1 dataset was compared and checked for anomalies. To describe the climatic signal of Turkey oak populations along the longitudinal gradient, Pearson's correlations were computed between the RW standard chronologies for each sampled site and between monthly total precipitation $(P)$ and mean monthly temperature $(T)$ for the common period 1998 - 2012, using a 19-month window from April in the year prior to treering formation (year $t-1$ ) until October in the year of growth (year $\mathrm{t}$ ). In addition, correlation functions were calculated between the three chronologies represented by the first principal components (PC1) and regional climate data. For this analysis we built a regional climatic dataset by averaging the values of climatic variables for the region encompassed by the coordinates $40^{\circ} 25^{\prime}-42^{\circ} 25^{\prime} \mathrm{N}$ and $19^{\circ} 25^{\prime}-20^{\circ} 25^{\prime} \mathrm{E}$. The regional climatic dataset was then used to study the radial growth climate relationship at the regional scale [30]. Significance and confidence intervals of Pearson's correlation coefficients were calculated using SPSS 17 software.

\section{RESULTS}

\section{Characteristics of the Site Chronologies}

The length of the chronologies ranged from 16 to 36 years, with the ELB site chronology being the longest and the BEL chronology the shortest one (Figure 3). Trees at lower elevations were younger than trees at higher elevations. The height and diameter at breast height varied between sites reaching the highest value in ELB site and the lowest in RESH site (Table 1).

The mean correlation among trees (MC) which ranks from 0.16 (DIB, 22 years) to 0.47 (KUK, 28 years) was considered significant at the $p<0.05$. Statistical parameters (MS 


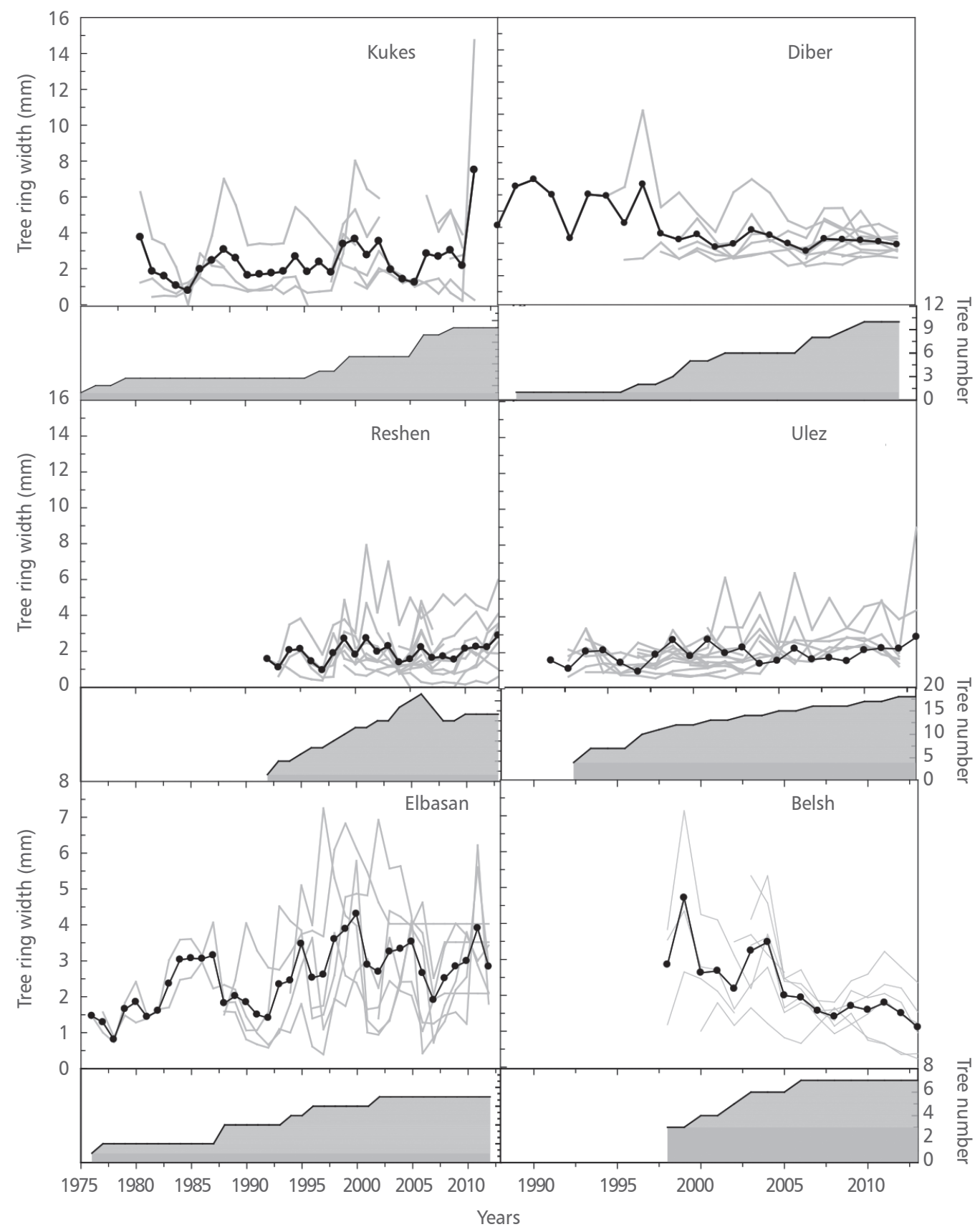

FIGURE 3. Raw tree-ring width chronologies of Turkey oak (Quercus cerris L.) (grey lines) and the arithmetic mean (black circle solid lines) of studied sites. Upper part of the figure is the raw tree-ring width chronology of the sampled site; lower part shows sample replication. 
and AC1, Table 2) indicate heterogeneous values within the six chronologies, with UL site chronology displaying the lowest mean sensitivity and DIB site chronology showing the lowest first-order autocorrelation. All chronologies showed a lower value of AC1 indicating a weaker dependence of current oak radial growth than of the growth of the previous year. The EPS for all site chronologies was higher than the critical value of 0.85 on the common period 1998-2012 (Table 2).

\section{Multidimensional Analysis}

The PCA was run for each site chronology (Figure 4a). It is well known that the most relevant numerical result of PCA is the percentage inertia as a measure of the importance of a component. In the RW analysis, the first principal component explains $36.64 \%$ of the total inertia and the second component contributes up to $58.8 \%$. The principal component analysis showed that $B E$, RRE and ELB site chronologies clustered in the first principal component accounted $36.6 \%$ of the whole variance, while UL site chronology contributes in the second principal components with $22.2 \%$.

The RW chronologies dendrogram obtained from the HFC analysis (Figure 4b) has grouped the existing site chronologies in two clusters.
RRESH, BEL and ELB site chronologies have been grouped in the first cluster while KUK, DIB and UL have been grouped in the second one.

\section{Growth-Climate Relationship}

Correlation analysis showed that the most distant sites showed a higher sensitivity and a reverse response against temperature (Figure 5). Most of the sites showed significant negative correlation with current June temperatures as well as with current September and October precipitation. Ring width chronologies from RRESH and UL sites showed significant and positive relationship with current July temperature. Considering the temperature impact on tree radial growth, especially during summer months, the treering width of sampled trees at UL and BEL sites was negatively affected by high June temperatures. Moreover, previous July and August temperatures showed a significant positive correlation with RW growth of trees in these sites.

The correlation analysis pointed out a significant positive correlation of radial growth with April precipitation, highlighting the importance of water in early wood growth. The correlation function performed for the first component (PC1) of RW confirmed the positive influence of current June and previous

TABLE 2. Statistical parameters of site chronologies for each sampled site

\begin{tabular}{llllll}
\hline \multirow{2}{*}{ Site } & \multicolumn{5}{c}{ Total tree-ring width } \\
\cline { 2 - 5 } & MC & MS & AC1 & Corr & EPS > 0.85 \\
\hline Kukes (KUK) & 0.47 & 0.25 & 0.54 & -0.58 & $1990-2012$ \\
Diber (DIB) & 0.16 & 0.30 & 0.27 & -0.12 & $1995-2012$ \\
Rreshen (RRESH) & 0.35 & 0.29 & 0.48 & 0.81 & $1998-2012$ \\
Ulez (UL) & 0.17 & 0.19 & 0.51 & -0.15 & $1997-2012$ \\
Elbasan (ELB) & 0.21 & 0.35 & 0.44 & 0.64 & $1980-2012$ \\
Belsh (BEL) & 0.46 & 0.25 & 0.56 & 0.87 & $1998-2013$ \\
\hline
\end{tabular}

MC - mean correlation between trees; MS - mean sensitivity; AC1 - First order Autocorrelation;

Corr - Correlation between site chronology and first principal component; EPS - Expressed Population Signal 
July and September precipitation over radial growth at a regional scale. Negative correlation found between PC1 and July temperature of the current growing year was consistent with the same relationship found for KUK site (Figure 6).
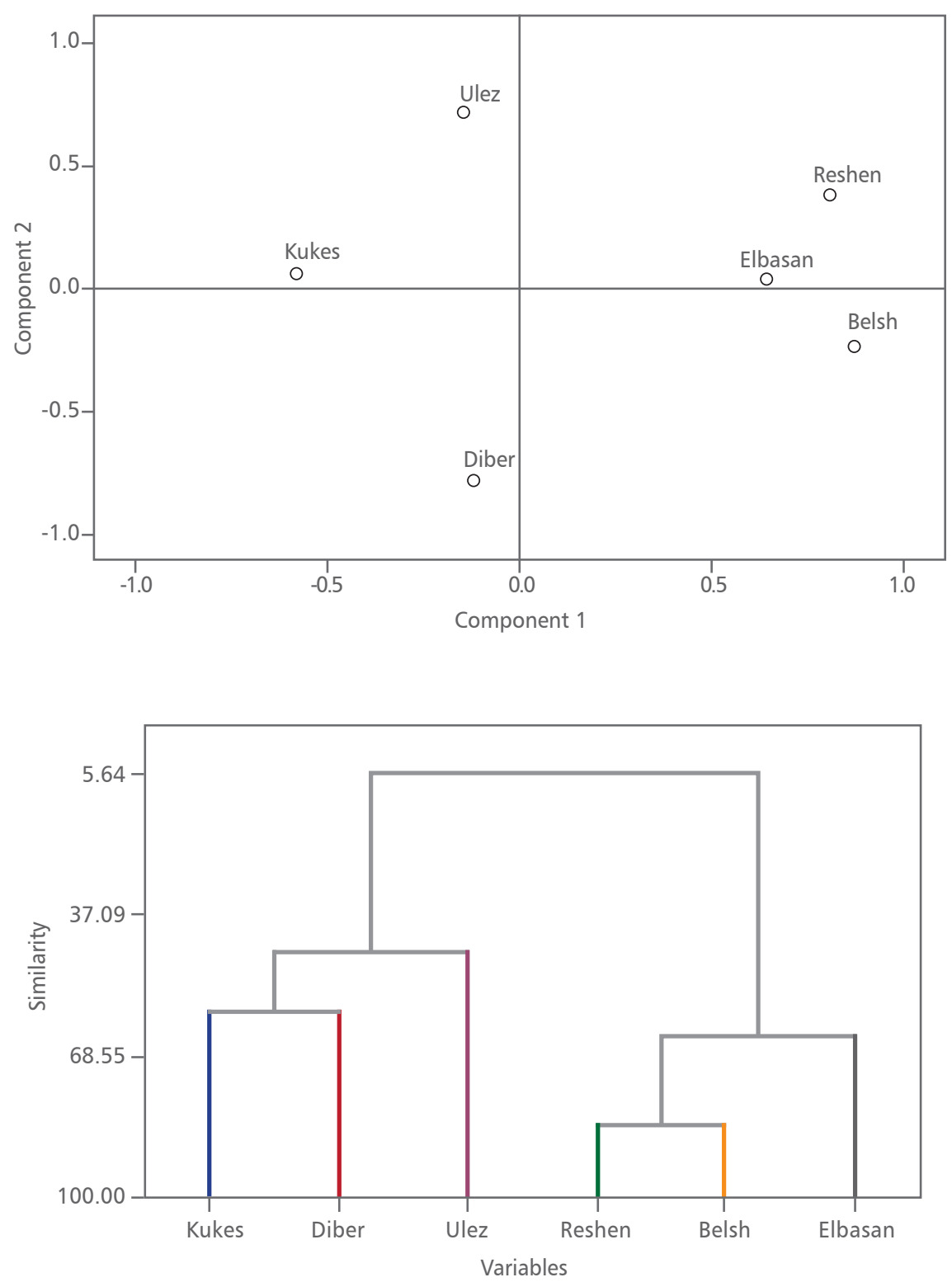

FIGURE 4. The multidimensional analysis between site chronologies in the sampled sites ( $a$ - the pattern of the chronologies on the planes spanned by the first two principal components of PCA-s; $\mathrm{b}$ - the dendrogram created by HFC of the site chronologies of the tree-ring width). 


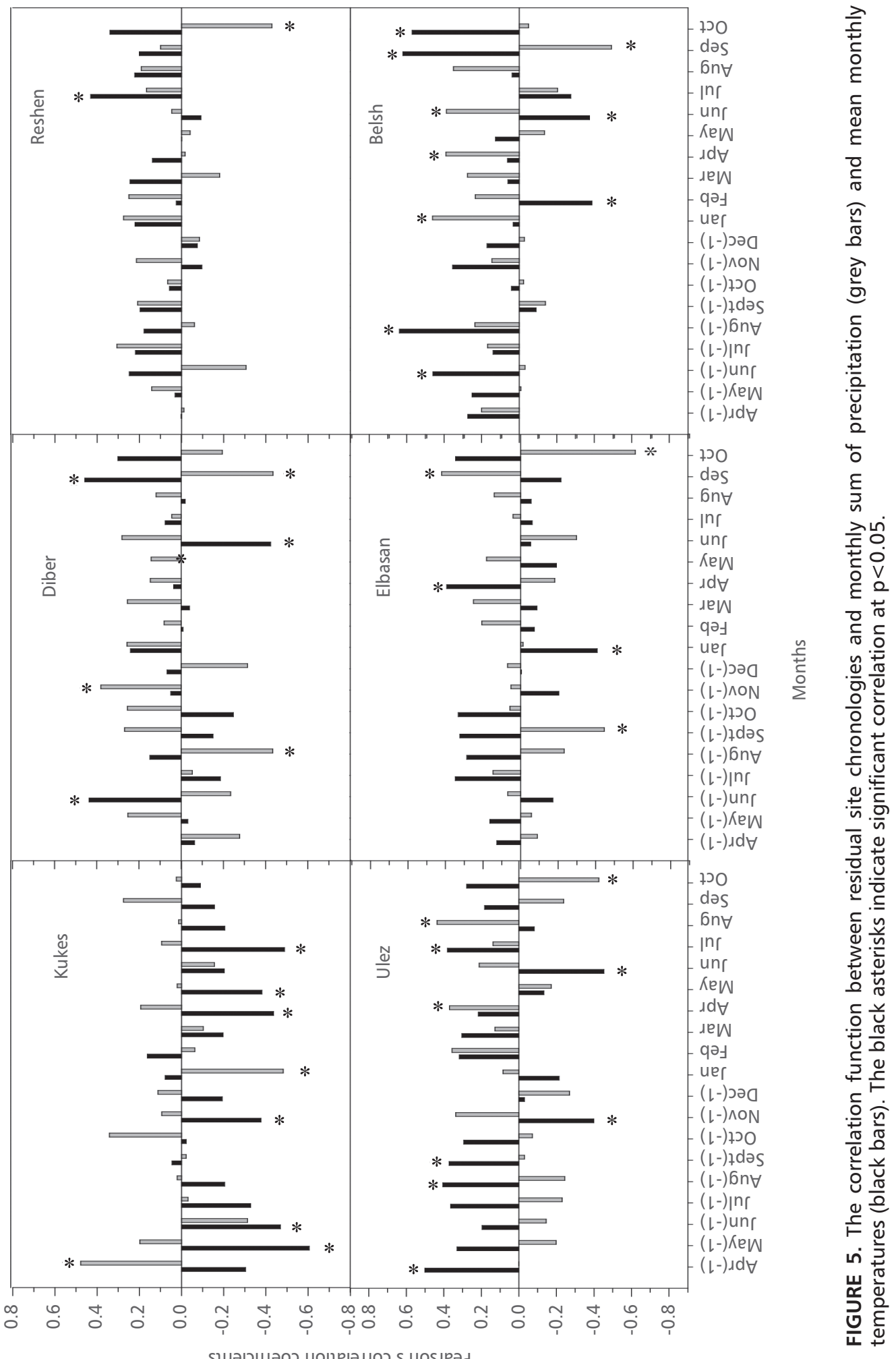

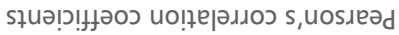




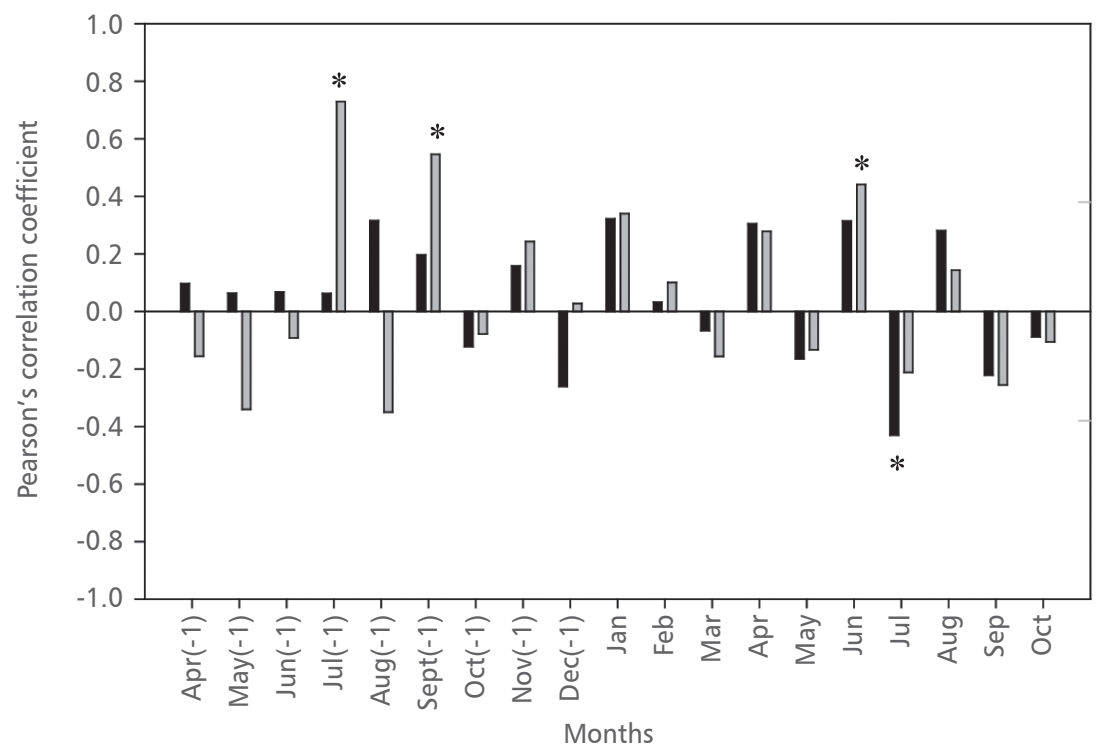

FIGURE 6. Correlation functions between PC1 of the first PCA on sites chronologies for total tree ring width and monthly sum of precipitation (grey bars) and mean monthly temperatures (black bars). The black asterisks indicate significant correlation at $p<0.05$.

\section{DISCUSSION}

Our study provides evidence about the growth of young $Q$. cerris coppice forest stands along longitudinal gradient in Albania. These forest stands were from 16 to 36 years old, which caused a limitation in the climategrowth analysis because of the short time span. Statistical parameters (MS and AC1) corresponding to six different chronologies showed heterogeneous values according to the longitudinal spatial distribution. Therefore, we can infer that entire young Turkey oak populations have a non uniform sensitivity to local environmental conditions. The low values of first-order autocorrelation indicated a weak persistent lag effect in the growth of young oaks from previous year's radial growth.

The multidimensional analysis showed that ring width chronologies of BEL and RESH sites contributed more to the first axis than ELB chronology. It suggests the existence of a common climate signal in all chronologies mentioned above. On the other hand, the UL chronology had a higher contribution to the second axis compared to DIB and KUK chronologies. The most distant location of DIB and KUK chronologies regarding to both axes indicate the lack of common signals as found in other sites.

The correlation analysis showed that radial growth of Turkey oak at distant sites was more sensitive against temperature. Our analysis showed a contrasting relationship between KUK, DIB and BEL chronologies with previous June temperatures, but DIB and BEL chronologies showed the same negative relationship with current June temperatures. It implies that high temperatures in the early summer may induce increased water stress and a subsequent decrease in radial growth due to elevated water loss associated with evapotranspiration and soil water evaporation. The negative effect of June temperatures on young oak growth has been previously observed in several localities in Continental Europe [31, 32], in northern 
Spain $[33,34]$ and also in Mediterranean region $[35,36]$. The positive relation found with April precipitation indicates that the abundant precipitation during this month favors the development of the ring at the beginning of the growing season.

In addition, the positive relation of PC1 with June precipitation shows that water balance in this month is critical for phenology and auxology of deciduous oaks because of the internal flow requirements for ring-porous wood $[30,37]$. At the regional scale, the positive correlation with previous September, shows that precipitation during this month is very important for soil water recharge affecting directly the Turkey oak latewood formation and indirectly the early wood formation in the successive growing year. A previous autumn signal has been identified in other dendroclimatic studies of deciduous oaks, especially with regard to the earlywood formation [30]. This positive link has been previously observed in other studies [35, 38, 39] and could be ecophysiologicaly meaningful. Autumn moisture can have also a direct positive effect on root growth [40], so when the new growth cycle begins, in the following year the tree will have a much larger root structure and will therefore be in a position to grow more [41].

\section{CONCLUSION}

The approach used in this study highlighted the short-term climatic responses of young $Q$. cerris forest stands along longitudinal gradient. Young growth oaks showed a climatic response that was typical for this species not only to Albania but also in some Mediterranean countries and Continental Western Europe, with a negative relationship to current June temperatures. This study also showed that positive moisture balance in current April and previous September has favored the radial growth of this species in Albania.

This study is an important first step in understanding and anticipating the responses of young growth coppice stands to climate and a good basis to explore the age effect on climate - growth relationships which could also reflect physiological changes related to ageing.

\section{Acknowledgments}

This study was conducted in the framework of the doctoral studies close to the Department of Wood Technology. The authors thank S. Beqo and A. Buzali for their assistance related to the sample preparation as well as the reviewers for their helpful comments.

\section{REFERENCES}

1. NIXON KC 2006 Global and Neotropical Distribution and Diversity of Oak (genus Quercus) and Oak Forests. In: Kappelle M (ed) Ecological Studies, Vol. 185, Ecology and Conservation of Neotropical Montane Oak Forests. SpringerVerlag, Berlin, Heidelberg, Germany, pp 3-12

2. ANFI 2004 Albanian National Forest Inventory. Final report. Terms of Reference. Tirana, Albania, pp 1-140

3. DIDA M 2003 State of Forest Tree Genetic Resources in Albania. Working Paper FGR/62E. Forest Resources Development Service, Forest Resources Division. FAO, Rome, Italy, (unpublished)
4. MITRAKOS AK 1980 A theory for Mediterranean plant life. Acta Oecol 1: 245-252

5. TERRADAS J, SAVÉ R 1992 The influence of summer and winter water relationships on the distribution of Quercus ilex L. Vegetatio 99-100 (1): 137-145. DOI: http://dx.doi.org/10.1007/BF00118219

6. LARCHER W 2000 Temperature stress and survival ability of Mediterranean sclerophyllous plants. Plant Biosyst 134 (3): 279-295. DOI: http://dx.doi. org/10.1080/11263500012331350455

7. FRITTS HC 1976 Tree-Rings and Climate. Academic Press, London, UK. 567 p 
8. COOK ER, PEDERSON N 2011 Uncertainty, emergence and statistics in dendrochronology. In: Hughes MK, Swetnam TW, Diaz HF (eds) Dendroclimatology, Developments in paleoenvironmental research 11 . Springer, Dordrecht, The Netherlands, pp 77-112. DOI: http://dx.doi.org/10.1007/978-1-4020-5725-0_4

9. BEGUM S, NAKABA S, YAMAGISHI Y, ORIBE $Y$, FUNADA R 2013 Regulation of cambial activity in relation to environmental conditions, understanding the role of temperature in wood formation of trees. Physiol Plantarum 147 (1): 46-54. DOI: http://dx.doi.org/10.1111/j.13993054.2012.01663.x

10. CAMPELO F, NABAIS C, FREITAS H, GUTIERREZ E 2007 Climatic significance of tree ring width and intra-annual density fluctuations in Pinus pinea from a dry Mediterranean area in Portugal. Ann For Sci 64 (2): 229-238. DOI: http://dx.doi. org/10.1051/forest:2006107

11. DI FILIPPO A, ALESSANDRINI A, BIONDI F, BLASI S, PORTOGHESI L, PIOVESAN G 2010 Climate change and oak growth decline: Dendroecology and stand productivity of a Turkey oak (Quercus cerris L.) old stored coppice in Central Italy. Ann For Sci 67 (7): 706. DOI: http://dx.doi.org/10.1051/ forest/2010031

12. ROMAGNOLI M, CODIPIETRO G 1996 Pointer years and growth in Turkey oak (Quercus cerris L) in Latium (central Italy). A dendroclimatic approach. Ann For Sci 53: 671-684. DOI: http://dx.doi. org/10.1051/forest:19960245

13. STOJANOVIĆ D, LEVANIČ T, MATOVIĆ B, GALIĆ Z, BAČKALIĆ T 2014 The Danube water level as a driver of poor growth and vitality of trees in the mixed pedunculate oak-Turkey oak stand (in Serbian with English summary). Šumarstvo 3-4: 153-160

14. JANOUS D, BARTAK M 1991 Dendroclimatological study of Turkey oak (Quercus cerris L) at Bab (SW Slovakia). Ekol (CSFR). 10 (1): 31-42

15. CORONA E 1987 The Dendrochronology in Italy: situation and applications (in Italian). Italian Botanical Informant 19: 67-76

16. ACADEMY OF SCIENCES 1975 Meteorological Bulletin for the 1931-2001 years (in Albanian). Hydrometeorological Institute, Tirana, Albania

17. BAILLIE LMG, PILCHER RJ 1973 A simple crossdating program for tree-ring research. Tree-ring Bulletin 33: 7-14.
18. ECKSTEIN D, BAUCH J 1969 Contribution to the rationalization of a dendrochronological method and to analyze its confidence level (in German). Forstwiss Centralb/ 88: 230-250

19. HOLMES RL 1983 Computer-assisted quality control in tree-ring dating and measurement. Tree-ring Bulletin 43: 69-78

20. COOK RE, BRIFFA RK 1990 A comparison of some tree-ring standardization methods. In: Cook ER, Kairiukstis LA (eds) Methods of Dendrochronology: Applications in the Environmental Sciences. Kluwer Academic Publishers, Dordrecht, The Netherlands, pp 153-162

21. COOK RE, HOLMES LR 1999 Program ARSTAN chronology development with analysis (user's manual for program ARSTAN). Tucson: Laboratory of Tree-Ring Research, University of Arizona, USA, $18 p$

22. WIGLEY TML, BRIFFA KR, JONES PD 1984 On the average value of correlated time-series, with applications in dendroclimatology and hydrometeorology. J Clim Appl Meteorol 23 (2): 201-213. DOI: http://dx.doi.org/10.1175/15200450(1984)023<0201:OTAVOC > 2.0.CO;2

23. ORLÓCI L 1978 Multivariate Analysis in Vegetation Research. Springer, Dordrecht, The Netherlands, $452 \mathrm{p}$

24. LEGENDRE P, LEGENDRE L 1998 Numerical Ecology, Second English Edition. Elsevier, , Amsterdam, The Netherlands, $853 \mathrm{p}$

25. GUTTMAN L 1954 Some necessary conditions for common factor analysis. Psychometrika 19 (2): 149-162. DOI: http://dx.doi.org/10.1007/ BF02289162

26. DENIMAL J 2001 Hierarchical Factorial Analysis. In: Govaert G, Janssen J, Limnios N (eds) Proceedings of the ASMDA 2001, Tenth International Symposium on Applied Stochastic Models and data Analysis, Compiègne, France, 12-15 June 2001. University of Technology of Compiègne, Compiègne, France, pp 369-374

27. CAMIZ S, DENIMAL JJ, PILLAR VD 2006 Hierarchical Factor Classification of Variables in Ecology. Community Ecol 7 (2): 165-179. DOI http://dx.doi. org/10.1556/ComEc.7.2006.2.4

28. CAMIZ S, PILLAR VD 2007 Comparison of Single and Complete Linkage Clustering with the Hierarchical Factor Classification of Variables. Community Ecol 8 (1): 25-30. DOI: http://dx.doi. org/10.1556/ComEc.8.2007.1.4 
29. MITCHELL TD, JONES PD 2005 An improved method of constructing a database of monthly climate observations and associated highresolution grids. Int J Climatol 25 (6): 693-712. DOI: http://dx.doi.org/10.1002/joc.1181

30. CORCUERA L, CAMARERO JJ, GIL_PELEGRIN E 2004 Effects of a severe drought on growth and wood-anatomical properties of Quercus faginea. IAWA J 25: (2): 185-204. DOI: http://dx.doi. org/10.1163/22941932-90000360

31. GRAY MB, PILCHER RJ 1983 Testing the significance of summary response functions. Tree-ring Bulletin 43: $31-38$

32. GRAY MB, WIGLEY TML, PILCHER RJ 1981 Statistical significance and reproducibility of treering response functions. Tree-ring Bullettin 41: 21-35

33. PÉREZ AA, FERNÁNDEZ AC 1997 Dendroclimatic reconstruction of the last of the XVIII century in Galicia(Spain) (in Spanish). Inv Agrar-Sist Rec. F 6 $(1-2): 17-37$

34. ROZAS V 2001 Detecting the impact of climate and disturbances on tree-rings of Fagus sylvatica $\mathrm{L}$. and Quercus robur L. in a lowland forest in Cantabria, Northern Spain. Ann For Sci 58 (3): 237-251. DOI: http://dx.doi.org/10.1051/forest:2001123

35. SANTINI A, BOTTACCI A, GELLINI R 1994 Preliminary dendroecological survey on pedunculate oak (Quercus robur L.) stands in Tuscany (Italy). Ann For Sci 51 (1) : 1-10. DOI: http://dx.doi. org/10.1051/forest:19940101
36. TESSIER L, NOLA P, SERRE-BACHET F 1994 Deciduous Quercus in the Mediterranean region: tree-ring/climate relationships. New Phytol 126 (2): 355-367. DOI: http://dx.doi. org/10.1111/j.1469-8137.1994.tb03955.x

37. ZWEIFEL R, ZIMMERMANN L, ZEUGIN F, NEWBERY DM 2006 Intraannual radial growth and water relations of trees: implications towards a growth mechanism. J Exp Bot 57 (6): 1445-1459. DOI: http://dx.doi.org/10.1093/jxb/erj125

38. NOLA P 1996 Climatic signal in earlywood and latewood of deciduous oaks from northern Italy. In: Dean SJ, Meko MD, Swetnam WT (eds), Tree Rings, Environment, and Humanity, Proceedings of the International Conference, Tucson, Arizona, 17-21 May 1994. Radiocarbon; Tucson, AZ, USA, pp 249-258

39. ORCEL A, ORCEL C, FAVRE A, MOHNHAUPT M, HURNI JP 1992 Dendroclimatic model constructed with oakwoods of the Swiss Piémont Jurassien. In: Bartholin ST, Berglund E, Eckstein D, Schweingruber HF, Eggertsson $\mathrm{O}$ (eds) Tree Rings and Environment, Proceedings of the International Symposium, Ystad, South Sweden, 3-9 September 1990. Lund University Lund, Sweden, pp 247-253

40. WEBER P, BUGMANN H, RIGLING A 2007 Radial growth responses to drought of Pinus sylvestris and Quercus pubescens in an inner-Alpine dry valley. J Veg Sci 18 (6): 777-792. DOI: http://dx.doi. org/10.1111/j.1654-1103.2007.tb02594.x

41. LEBOURGEOIS F, COUSSEAU G, DUCOS Y 2004 Climate-tree-growth relationships of Quercus petraea Mill. stand in the Forest of Bercé ("Futaie des Clos", Sarthe, France). Ann For Sci 61 (4): 361-372. DOI: http://dx.doi.org/10.1051/ forest:2004029

(C) 2015 by the Croatian Forest Research Institute. This is an Open Access paper distributed under the terms of the Creative Commons Attribution License (http://creativecommons.org/licenses/by/4.0). 